\title{
Variasi Genetik pada Rusa Sambar (Rusa unicolor) di Penangkaran, Kabupaten Penajam, Kalimantan Timur
}

\section{Genetic Variations within Captive Sambar Deer (Rusa unicolor) in Penajam District, East Borneo Province}

\author{
Wirdateti $^{1}$, Bram Brahmantyo ${ }^{2}$, Gono Semiadi ${ }^{1}$ dan Andi Reksodihardjo $^{3}$ \\ ${ }^{1}$ Bidang Zoologi, Puslit, Biologi-LIPI \\ ${ }^{2}$ Balai Penelitian Ternak, Puslitbangnak-DEPTAN \\ ${ }^{3}$ Dinas Pertanian, Peternakan dan Perikanan Kabupaten Penajam-Kaltim \\ E-mail: teti_mzb@yahoo.com*Penulis untuk korespondensi
}

\begin{abstract}
Sambar deer (Rusa unicolor) is the largest Indonesian deer species. The largest population of captivation is located at Penajam district, East Borneo (UPTD). First population was introduced in 1990 with four individuals. The use of molecular marker was aimed to identify and characterise the level of genetic diversity within the UPTD population as well as to identify a possible of botolneck population genetic status. This study discussed the relevance of the result for management purposes of captivation. The results indicated that sambar deer populatin $(n=38)$ had an average genetic distance $(d)$ in population as 0.006 with nucleotide diversity $(\pi)$ being 0.0159$)$. A total of $43.48 \%$ of the population was homogeneous that showed no nucleotide differences among individuals.
\end{abstract}

Key words: Sambar deer, Rusa unicolor, molecular, captive breeding, genetic diversity

\begin{abstract}
Abstrak
Rusa sambar (Rusa unicolor) adalah salah satu jenis rusa yang ada di Indonesia. Populasi yang besar di dalam penangkaran terdapat di wilayah sebaran rusa sambar berlokasi di UPTD Pembibitan dan Inseminasi Buatan wilayah Kabupaten Penajam, Kaltim. Keberadaan rusa di penangkaran tersebut dimulai pada tahun 1990, dengan memasukkan empat individu rusa sambar ke dalam area penangkaran. Penelitian ini akan membahas hasil yang berhubungan untuk tujuan pengelolaan indukan di penangkaran. Penggunaan marker molecular bertujuan menentukan atau mencirikan level keragaman genetik di dalam populasi rusa di UPTD dan mengidentifikasi kemungkinan populasi botolneck. Hasil menunjukkan bahwa populasi rusa sambar di UPTD ( $n=38$ ) mempunyai rata-rata jarak genetic (d) antarindividu hanya 0,006 dengan perbedaan nucleotide $(\pi)$ 0,0159. Sebanyak $43,58 \%$ dari populasi yang diuji adalah homogeny, yakni tidak menunjukkan perbedaan nucleotide di antara individu.
\end{abstract}

Key words: Rusa sambar, Rusa unicolor, molecular, penangkaran, keragaman genetik

Diterima: 25 Februari 2010, disetujui: 28 September 2010

\section{Pendahuluan}

Rusa sambar (Rusa unicolor) yang tersebar di Indonesia sampai saat ini statusnya masih dilindungi. Berdasarkan Undang-Undang Nomor 5 Tahun 1990 dalam Peraturan Pemerintah No. 8 Tahun 1999, rusa dapat dimanfaatkan dari hasil penangkaran pada turunan kedua (F2) tetapi dengan tetap mempertahankan kemurniannya. Rusa merupakan suatu satwa alternatif harapan terbaik untuk dikembangkan mengingat ketersediaannya hampir di setiap pulau di Indonesia (Whitehead, 1993). Dalam rangka upaya memperluas sumber konsumsi protein di tingkat masyarakat, dan dalam rangka memenuhi ketahanan pangan, rusa telah dimasukan dalam kelompok aneka ternak oleh Departemen Pertanian sejak tahun 1990 dan diperbaharui tahun 2002. Pemanfaatan rusa sebagai sumber protein telah dilakukan di daerah sebaran rusa ataupun di luar daerah sebaran, tetapi pemanfaatannya secara illegal. Di luar 
negeri rusa sudah merupakan bagian dari diversifikasi usaha peternakan dan pemanfaatan hidupan liar sejak 20 tahun yang lampau. Industri peternakan rusa asal daerah tropika di negara sub-tropika dan tropik seperti Thailand, Australia dan China menggunakan rusa asli Indonesia, yaitu Rusa Jawa (Rusa timorensis). Di luar negeri, peternakan rusa terbukti sangat potensial, baik untuk dipanen daging maupun ranggah mudanya dan produk sampingan lainnya seperti kulit (Haigh dan Hudson, 1993).

Unit Pelaksana Teknis Daerah (UPTD) Balai Pembibitan dan Inseminasi Buatan Dinas Peternakan Tingkat I dari Kalimantan Timur, Kabupaten Penajam sejak tahun 1990 menangkarkan rusa sambar dengan membangun Pusat Penangkaran Rusa Sambar. Kegiatan penangkaran dimulai empat ekor rusa sambar yang diperoleh dari sekitar wilayah Penajam kemudian dilakukan beberapa penambahan indukan. Sampai saat ini rusa tersebut sudah berkembang menjadi 240 ekor rusa yang dipelihara dalam sistem pedok. Pengamatan terhadap penampilan genetik rusa di penangkaran secara umum menunjukkan kualitas rusa dewasa yang rendah yaitu hanya sekitar 70-80 kg/ekor. Capaian berat badan dewasa rusa sambar tersebut terlihat jauh dibawah berat rata-rata yaitu 100 kg/ekor (Semiadi, 2005). Perubahan ini akan memberikan pengaruh terhadap pengelolaan Pengembangan Rusa di UPTD. Pengelolaan yang efektif membutuhkan suatu struktur genetik dan habitat atau lingkungan sebagai kontrol dalam populasi yang dikembangkan. Secara komersial penangkaran rusa di UPTD Penajam untuk venison dan velvet antler sebagai supelmen kesehatan, demikian juga peternakan rusa di luar negeri seperti di negara Australia, peternakan rusa sudah mempunyai pasar untuk venison, dan velvet antler (Tuckwell, 2001; 2003). Sampai saat ini belum ada data genetik untuk program seleksi dalam pengembangbiakan (breeding) rusa di Australia.

Pemasukan hewan jenis eksotik ke dalam area baru biasanya terdiri dari jumlah populasi kecil dan khususnya pada hewan yang relatif ukuran tubuh besar seperti rusa. Pemasukan yang demikian sering berpengaruh terhadap terjadinya populasi botolneck karena hilangnya allele, penurunan jumlah allele dan heterozygosity akibat tekanan kawin dalam (inbreeding) yang menyebabkan penurunan keragaman genetik (Zein, 2007). Keragaman genetik pada populasi di peternakan atau penangkaran umumnya disebabkan oleh aktivitas manusia. Biasanya populasi di peternakan mempunyai keragaman genetik tinggi pada tingkat level species karena tujuan program breeding terutama untuk mendapatkan keragaman phenotipik untuk sejumlah sifat tertentu (Anderson, 2001) seperti warna bulu, komposisi tubuh dan daya tahan penyakit. Kejadian botolneck meliputi berkurangnya allele, diikuti oleh penurunan jumlah rata-rata dari allele dan heterozygosity (Luikart et al., 1998). Kemudian dapat juga disebabkan oleh fixasi allele dari hilangnya allele dan tekanan inbreeding (Frankham, 1995; Luikart et al., 1998). Kejadian genetik botolneck telah didokumentasi terjadi pada beberapa species rusa yang didukung oleh data molekular (Broders et al., 1999; Lenney Williams et al., 2002 in Webley et al., 2004). Akan tetapi tidak semua populasi kecil mengalami penurunan keragaman genetik seperti pada rusa berekor putih (White-tailed deer/ Odocoileus virginianus) di Missisippi (DeYoung et al., 2003). Tujuan penelitian ini untuk menguji tingkat keragaman genetik rusa sambar di penangkaran dan identifikasi polymorphic yang dapat digunakan untuk struktur keturunan dalam populasi. Informasi ini berguna dalam seleksi perkawinan dalam program usaha komersial atau pengembangbiakan di penangkaran.

\section{Metode Penelitian}

Sampel darah dikoleksi dari populasi rusa sambar (jantan $=5$ dan betina = 33) di Penangkaran UPTD Balai Pembibitan dan Inseminasi Buatan Dinas Peternakan Kaltim di Penajam lewat vena jungularis. Koleksi darah dilakukan pada kandang jepit (deer crush) menggunakan jarum suntik (16 G, 1 inch) dan preservasi (diawetkan) dengan $10 \%$ EDTA. DNA diekstrak menggunakan NHCl4 buffer dan dipurifikasi dengan Etanol absolute. Control region mtDNA digunakan untuk identifikasi level keragaman genetik dan identifikasi polymorphic. Penggunaan control region adalah 
berdasarkan tingginya kejadian mutasi (substitusi, delesi atau insersi) basa di daerah tersebut. Control region dan $\mathrm{CytB}$ diamplifikasi melalui polymerase chain reaction (PCR) menggunakan primer CR (Douzery, 1997) yaitu: Forward 5'-AAACCAGAAAAGGAGAGCAAC-3 dan reverse 5-TCATCTAGGCATTTTCAGTGCC3; Mix PCR dalam 25 ul volume 100-200 ng genom DNA; $10 \mathrm{mM}$ Tris- $\mathrm{HCl}(\mathrm{pH} 8,3) ; 50 \mathrm{mM}$ $\mathrm{KCl} ; 1,5-3,0 \mathrm{mM} \mathrm{MgCl} 2$; 10um dNTP, 2,5 pm primers, 5 U Taq Polymerase dan MQ. Kondisi PCR 5 min pada $95^{\circ} \mathrm{C}$ denaturasi, $95^{\circ} \mathrm{C}$ selama $30 \mathrm{det}, 58^{\circ} \mathrm{C}$ selama $30 \mathrm{det}$ (annealing), $72^{\circ} \mathrm{C}$ selama 1 menit sebanyak 40 siklus (elongasi); dan final elongasi $10 \mathrm{~m}$ pada $72^{\circ} \mathrm{C}$.

Analisis kualitatif (genetik) dari data nucleotide untuk penjajaran homologi sekuen nukleotida dilakukan dengan perangkat lunak Clustal X (Jeanmougin et al., 1998). Adapun analisis keragaman dari struktur genetik dilakukan dengan menggunakan perangkat lunak MEGA Vers. 4.0 (Tamura et al., 2007).

\section{Hasil dan Pembahasan}

Analisis genetik dalam menentukan variasi genetik dan tingkat keragaman adalah pada daerah control region mitochondrial DNA. Dalam analisis ini menggunakan tiga sekuen dari Gene Bank yaitu Rusa unicolor, R. unicolor swinoi (India) dan $R$. unicolor hainana (China) sebagai pembanding.

Jumlah individu yang disekuen pada daerah control region adalah sebanyak 38 individu dari 69 individu yang terseleksi. Panjang sekuen nukleotide yang digunakan untuk analisis sepanjang 929 "base pair" (bp) merupakan bagian kiri dari control region yang disebut $D$-loop. $D$-loop merupakan daerah yang sering mengalami mutasi basa baik secara substitusi basa, delesi ataupun insersi basa. Dengan demikian daerah tersebut sering digunakan untuk melihat keragaman atau kualitas dari suatu popualsi (Sbisa et al., 1997).

Dari jajaran sekuen 929 bp nukleotida terjadi penggantian basa pada 87 situs tidak termasuk delesi dan insersi basa. Dari 87 situs tersebut memberikan 22 haplotipe yang diperoleh dari substitusi nukleotide pada situs yang berbeda. Kehadiran haplotipe lebih banyak disebabkan oleh perbedaan sekuen tinggi antara populasi UPTD dengan sekuen dari gene bank yang ditandai dengan jarak genetic tinggi (diatas 95\%). Perubahan nukleotide pada basa purine dan pyrimidine atau Transisi (S) tertinggi adalah basa Cytosine (C) ke Timine (T) $(31,02 \%$; Timine ke Cytosine (22,71\%); Guanine (G) ke Adenine (A) $(20,44 \%)$ dan Adenine ke Guanine $(11,14 \%)$. Adapun perubahan nucleotide dari basa purine ke pyrimidine atau Transversi (V) adalah dari T ke A $(2,23 \%)$, A ke T $(2,25 \%)$; T ke G ( $1,22 \%)$, G ke T (2,25\%); C ke A (2,23\%), C ke G (1,22\%); A ke C (1,65\%) dan G ke C $(1,65 \%)$. Index laju perubahan basa secara transisi dan transversi $(\mathrm{R}=\mathrm{S} / \mathrm{V})$ adalah $\mathrm{R}=$ 4,619 atau 0,04619\% (Tabel 1).

Nilai ratio ini menurut Brown et al., (1982) dalam Nei (1983) menunjukkan bahwa waktu pemisahan species rusa sambar tejadi $\leq 8$ juta tahun lalu. Haplotipe yang berbeda menunjukkan adanya variasi nukleotide dari sekuen populasi yang diuji, tetapi tingkat keragaman dari populasi tersebut mengindikasikan variasi genetik rendah yang ditunjukkan perbedaan nukleotida genetik diantara individu dalam populasi menunjukkan index yang rendah yaitu $0,000-0,040$ (Tabel 2). Pada Tabel 3, terlihat sebanyak 17 individu $(43,58 \%)$ menunjukkan tidak ada perbedaan nukleotide sepanjang 929 bp jajaran sekuen (0.000) yang artinya tidak terdapat variasi genetik, 10 individu $(25,64 \%)$ menunjukkan perbedaan nukleotide di bawah $1 \%(0,001$ 0,009) dan 11 individu (30,76\%) menunjukkan perbedaan nukleotida dibawah $4 \% \quad(0,012-$ 0,040). Hasil tersebut menunjukkan bahwa dalam populasi tersebut terjadi penurunan kualitas genetik yang tentunya akan berpengaruh pada ukuran populasi efektif yaitu individu yang berperan dalam perkembangbiakan ( $\mathrm{Li}$ and Graur, 1991). Rata-rata jarak genetik diantara individu dalam populasi adalah $\mathrm{d}=0,006$. Adapun analisis Tajima's untuk keragaman nukleotide $(\pi)$ adalah 0,0159 . Index jarak genetik tersebut lebih rendah apabila dibandingkan dengan jarak genetik pada populasi peternakan rusa merah (red deer) yaitu 0,016 (Gyllensten et al., 1983 dalam Nei, 1987. Rendahnya perbedaan nukleotida dan keragaman nukleotida di dalam populasi yang diuji, dan tingginya tingkat homogenitas sekuen mengindikasikan 
sudah terjadi in breeding tingkat tinggi di dalam populasi atau pada penangkaran rusa di UPTD Penajam. Hal ini mengingat tingginya tingkat perkawinan dalam keluarga sejak tahun 1990 saat mulai berdirinya penangkaran rusa tersebut. Dibandingkan dengan tiga sekuen Rusa unicolor dari Gene Bank menunjukkan bahwa perbedaan nukleotida dari ketiga sekuen tersebut terhadap populasi di penangkaran UPTD (38 ekor) memberikan persentase cukup tinggi yaitu sekitar 4\%-7\% pada komposisi sekuen yang sama. Analisis tingkat homogenitas sekuen pada individu yang diuji dapat dilihat pada Tabel 3. Hasil menunjukkan pada tingkat uji 5\% perbedaan nucleotide pada 38 individu populasi UPTD tidak menunjukkan perbedaan nyata. Tetapi homogenitas sekuen pada tingkat 5\% tersebut memiliki jarak genetik rendah (Tabel 2). Warna merah menunjukkan perbedaan signifikan diantara individu pada tingkat $5 \%$.

Secara keseluruhan dari analisis sekuen menunjukkan bahwa populasi rusa di penangkaran UPTD memiliki jarak genetik antar individu rendah yaitu berkisar $0.000-0.033$ (ratarata 0.006). Sementara sekuen rusa sambar dari gene Bank yang digunakan sebagai pembanding untuk identifikasi kondisi genetik pada populasi di UPTD menunjukkan perbedaan sekuen atau jarak genetik dengan populasi UPTD cukup tinggi yaitu berkisar 0,37-0,66 (Tabel 2). Beberapa penelitian menunjukkan bahwa introduksi atau pemasukan species ke area baru dalam jumlah kecil akan mempengaruhi struktur genetik dengan penurunan keragaman atau variasi genetik dan terbentuknya populasi botolneck (populasi dengan tingkat keragaman sangat kecil atau penurunan kualitas genetik yang sangat rendah akibat tekanan inbreeding sehingga struktur genetik menyerupai leher botol). Kejadian botolneck meliputi berkurangnya allele, diikuti oleh penurunan jumlah rata-rata dari allele dan rendahnya heterozygosity (Luikart et al., 1998). Kemudian dapat juga disebabkan oleh fixasi alele dari hilangnya allele dan akibat tekanan inbreeding (Frankham, 1995; Luikart et al., 1998). Kejadian genetik botolneck tersebut dilaporkan telah terjadi pada beberapa species rusa pada populasi di penangkaran yang didukung oleh data molecular (Broders et al., 1999; Lenney Williams et al., 2002 in Webley et al., 2004).
Namun, tidak semua populasi berukuran kecil mengalami penurunan keragaman genetik seperti halnya pada rusa berekor putih (White-tailed deer) di Missisippi (DeYoung et al., 2003) karena adanya pengaturan sistem perkawinan (breeding system) antara jantan dan betina dalam populasi. Mengingat populasi rusa sambar di UPTD mulai di inroduksi (masuk) ke area tersebut sejak tahun 1992 dengan jumlah empat ekor, dari komposisi nuklotide pada jarak genetik terlihat sudah terjadi penurunan keragaman genetik akibat tekanan in breeding, dan kemungkinan terbentuknya populasi botolneck akan terjadi apabila tidak ada perbaikan dalam struktur genetik di dalam management breeding. Pada skala lokal atau regional, struktur genetika populasi hewan yang di introduksi pada suatu tempat atau area mungkin dipengaruhi oleh tiga faktor alam atau faktor buatan manusia yaitu: status hewan ketika dimasukkan (tanggal dan jumlah individu), pengaruh aktivitas manusia terhadap reproduksi (sistem perkembangbiakan, translokasi, tekanan perberburuan), dan pola penyebaran yang dipengaruhi oleh kondisi ekologi setempat (Wchatitsky MdG et al., 2009; Zein, 2007).

Tingginya tingkat in breeding atau terjadinya penurunan keragaman genetik di dalam populasi terlihat dari penurunan bobot badan dewasa pada penangkaran yang secara umum berkisar 70-80kg/ekor pada betina dan 80-100kg/ekor pada jantan (Wirdateti et al., 2009). Capaian berat badan dewasa rusa sambar tersebut terlihat jauh di bawah berat rata-rata yang telah ada yaitu $135-225 \mathrm{~kg} /$ ekor pada betina dan 136-320kg/ekor pada jantan (Semiadi et al., 2005). Perubahan ini akan memberikan pengaruh terhadap pengelolaan Pengembangan Plan Rusa di UPTD. Manajemen yang efektif membutuhkan suatu struktur genetik dan habitat atau lingkungan sebagai kontrol dalam populasi yang dikembangkan. Hal yang perlu diperhatikan dalam manajemen breeding adalah kualitas jenis yang didasarkan pada populasi dengan tingkat keragaman sama (homogen) baik secara genetik maupun phenotipik dengan kestabilan sama. Secara genetik didasarkan pada keragaman homogen pada tingginya variasi genetik (nukleotide) dalam populasi, dan homogen pada phenotipik adalah dengan performance tinggi. Untuk kestabilan genetik 
perlu menggunakan pembanding dari profil genetik rusa sambar dari sebaran alam guna penentuan kualitas rusa sambar di penangkaran. Lebih dari itu, penggunaan marker molekular dapat digunakan untuk membantu membatasi peningkatan tingkat keturunan selama program seleksi.

Tabel 1. Analisis Tajima Test Program MEGA 4.0

\begin{tabular}{cccccc}
\hline \hline \multicolumn{5}{c}{ Maximum Composite Likelihood Estimate of the Pattern of Nucleotide Substitution [1] } \\
\hline & $\mathbf{A}$ & $\mathbf{T}$ & $\mathbf{C}$ & $\mathbf{G}$ \\
\hline \hline $\mathrm{A}$ & - & 2,25 & 1,65 & $\mathbf{1 1 , 1 4}$ \\
$\mathrm{T}$ & 2,23 & - & $\mathbf{2 2 , 7 1}$ & 1,22 \\
$\mathrm{C}$ & 2,23 & $\mathbf{3 1 , 0 2}$ & - & 1,22 \\
$\mathrm{G}$ & $\mathbf{2 0 , 4 4}$ & 2,25 & 1,65 & - \\
\hline \hline
\end{tabular}

Keterangan:

Komposisi perubahan basa (substitusi) scara transisi dan transversi

Transisi = Italic ;ransversi $=$ Bold

Tabel 2. Jarak Genetik pada indukan rusa sambar hasil seleksi berdasarkan bobot badan.

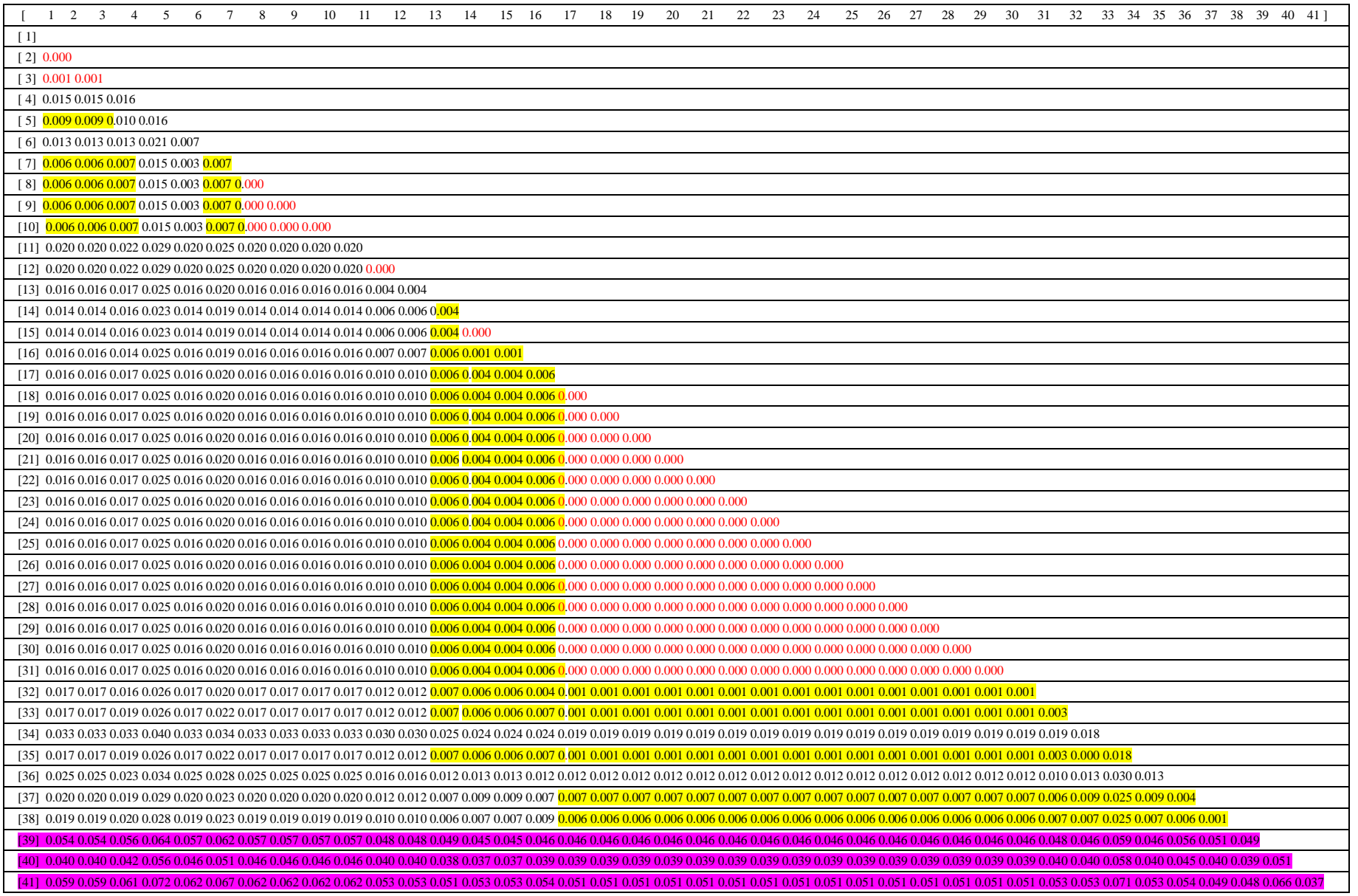

Keterangan: No. 1 - 38 adalah individu dari UPTD Penajam, Kalimantan Timur

No. 39 - 41 adalah sekuen rusa sambar dari Gene Bank 
Tabel 3. Tingkat homogenitas sekuen antar individu pada tingkat $5 \%$.

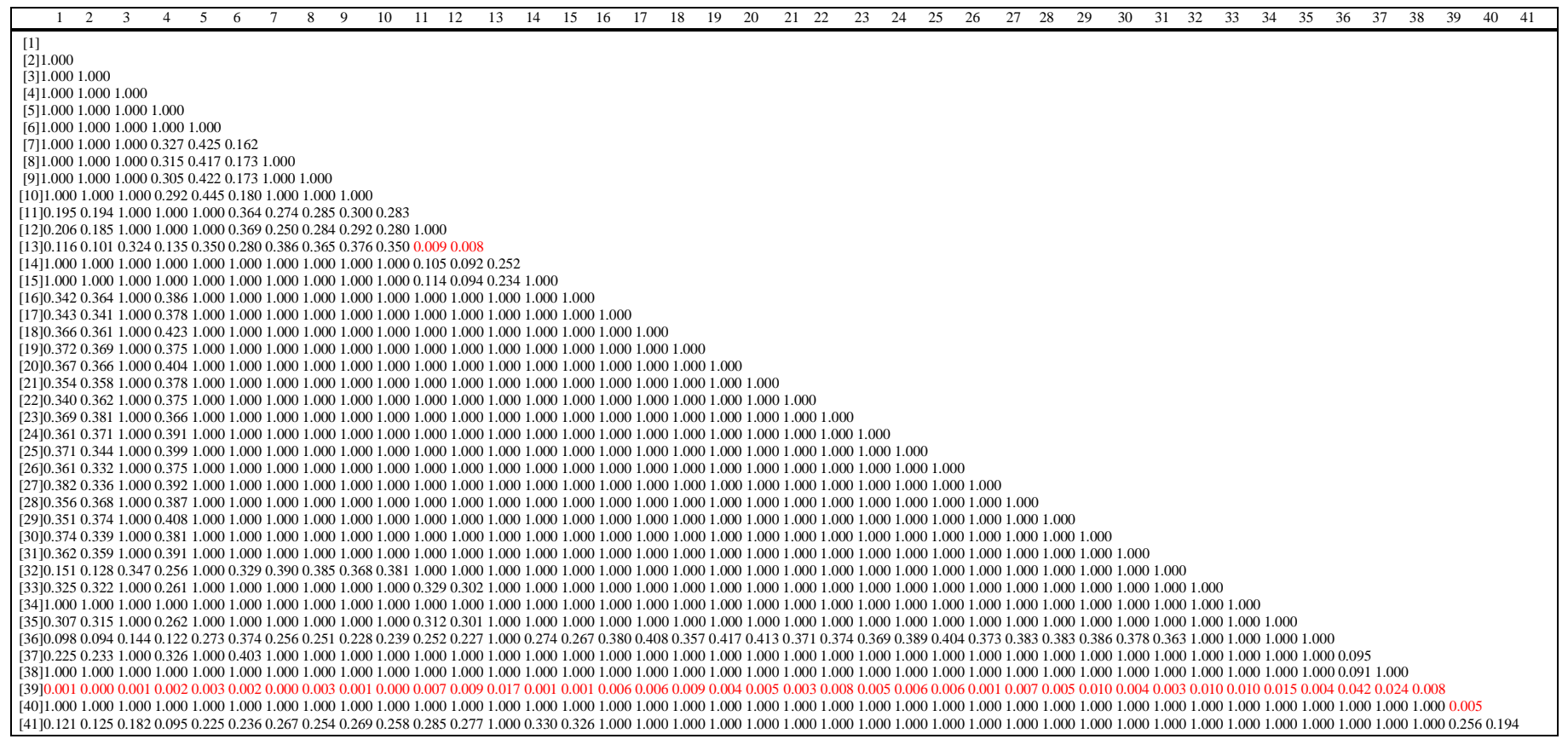

\section{Simpulan dan Saran}

\section{Simpulan}

Berdasarkan analisis genetik pada daerah control region mtDNA terhadap 38 individu dari 69 indukan terseleksi berbasiskan bobot badan dapat disimpulkan populasi rusa sambar di UPTD Penajam mengalami tingkat in breeding cukup tinggi dan penurunan kualitas genetik. Penggunaan marker molekular dapat digunakan untuk menentukan heritabilitas dari sifat-sifat ekonomi dalam pemeliharaan dan perbaikan program seleksi ternak rusa.

\section{Saran}

Penelitian ini perlu data pembanding dari populasi alam guna mengetahui kestabilan genetik rusa sambar. Untuk itu diharapkan perlu penelitian lanjutan analisis genetik dari sebaran rusa sambar alam asal Sumatra dan Kalimantan.

\section{Ucapan Terima Kasih}

Penulis mengucapkan terima kasih kepada Program Kompetitif LIPI yang membiayai penelitian. Terima kasih juga disampaikan kepada Dinas Peternakan Kaltim dan UPTD Balai Pembibitan dan Inseminasi Buatan Dinas Peternakan TK I Kalimantan Timur, Kabupaten Penajam yang telah membantu dalam penggunaan fasilitas penangkaran rusa sambar.

\section{Daftar Pustaka}

Anderson, L. 2001. Genetic Dissection of Phenotypic Diversity in Farm Animals. Nat.Rev.Genet., 2: 130-138.

DeYoung, R.W., Demarais, S., Honeycutt, R.L., Rooney, A.P., Gonzales, R.A. dan Gee, K.L. 2003. Genetic Consequences of White-tailed Deer (Odocoileus virginianus) Restoration in Mississippi. Mol. Ecol., 12: 3237-3252.

Douzery, E. dan Randi, E. 1997. The Mitochondrial Control Region of Cervidae: Evolutionary Patterns \& Phylogenetik Content. Molecular Biology and Evolution, 14: 1154-1166.

Frankham, R. 1995. Conservation Genetics. Annu. Rev. Genet., 29: 305-327.

Jeanmougin, F., Thomson, J.D., Gouy, M., Higgins, D.G. dan Gibson, T.J. 1998. Multiple Sequence alignment with Clustal X. Trends in Biochemical Sciences, 23: 403-405. 


\section{Wirdateti et al.,}

Haigh, J.C. dan Hudson, R.J. 1993. Farming Wapiti and Red Deer. St. Louis, USA. Mosby - Year Book Inc.

Li, W.H. dan Dan, G. 1991. Fundamentals of Molecular Evolution. Sinauer Associates, INC. Publisher. Sunderland, Massachusetts.

Luikart, G., Sherwin, W.B., Steele, B.M. dan Allendorf, F.W. 1998. Usefulness of Molecular Markers for Detecting Population Bottlenecks via Monitoring Genetic Change. Mol. Ecol., 7: 963-974.

Nei, M. dan Richard, K.K. 1983. Evolution of Genes and Proteins. Sinaeur Associates INC. Publisher. Sunderland. Massachusetts.

Nei, M. 1987. The Molecular Evolutinary Genetics. Columbia University Press. New York.

Sbisà, E., Tanzariello, F., Reyes, A., Pesole, G. dan Saccone, C. 1997. Mammalian Mitochondrial D-loop Region Structural Analysis: Identification of New Conserved Sequences and Their Functional and Evolutionary Implications. Gene, 205: 125-140.

Semiadi, G., Adhi, I.G.M.J. dan Trasidiharto, A. 2005. Pola Kelahiran Rusa Sambar (Rusa unicolor) di Penangkaran Kalimantan Timur. Biodiversitas, $6(1): 59-62$.

Tamura, K., Dudley, J., Nei, M. dan Kumar, S. 2007. MEGA4.: Molecular Evolutionary Genetics Analysis (MEGA) software version 4.0. Mol. Biol. Evol. DOI:10.1093/molbev/msm092.
Tuckwell, C. 2001. Deer: Quality Assurance, Strategic Alliances and Industry Development. Report for the Rural Industries Research and Development Corporation, Barton, ACT, Australia, Pp 63.

Tuckwell, C. 2003. The Deer Farming Handbook. Rural Industries Research and Development Corporation, Canberra, Australia

Webley, L.S., Zenger, K.R., English, A.W. dan Cooper, D.W. 2004. Low Levels of Genetic Variation within Introduced Javan Rusa Deer (Cervus timorensis russa) in Australia. European J. of Wildlife Reseach, 50 (3): 137-140.

Whitehead, G.K. 1993. Encyclopedia of Deer. Swann Hill Press. Shrewsbury. Pp 912.

Wichatitsky, M.d.G., de Meeus, T., Chevillon, C., Berthier, D., Barre, N., Thevenon, S. dan Maillard, J.C. 2009. Population Genetic Structure of Wild and Farmed Rusa Deer (Cervus timorensis russa) in New-Caledonia Inferred from Polymorphic Microsatellite Loci. Genetica. DOI 10.1007/9395-6.

Wirdateti, Brahmantiyo, B., Reksodiharjo, A., Semiadi, G. dan Dahrudin, H. 2009. Karakteristik Morfometrik Rusa Sambar (Rusa unicolor) sebagai Dasar Kriteria Seleksi Sifat Pertumbuhan. J. Veteriner, 10 (1): 7-11.

Zein, M.S.A. 2007. Keragaman Daerah Kontrol DNA Mitokondria Rusa Timor (Cervus timorensis timorensis) di Pulau Timor, Alor, dan Pantar. Biota, 12 (3): 138-144. 